DOI No: http://dx.doi.org/10.29228/Joh.51975

Authenticity process is conducted by

Makale Türü: Araştırma makalesi

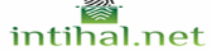

Geliş Tarihi: 01-07-2021

Kabul Tarihi: 26-08-2021

On-line Yayın: 31-08-2021

Article Type: Research article Submitted: 01-07-2021

Accepted: 26-08-2021

Published Online: 31-08-2021

Atıf Bilgisi / Reference Information

Kalyoncu, H. (2021). Motif-Oriented Characteristics of The Turkish Carpets Illustrated In English Aristocratic Portrays of Renaissance and Effects of The Carpets on British Carpet Production. Journal of History School, 53, 29923030 .

\title{
MOTIF-ORIENTED CHARACTERISTICS OF THE TURKISH CARPETS ILLUSTRATED IN ENGLISH ARISTOCRATIC PORTRAYS OF RENAISSANCE AND EFFECTS OF THE CARPETS ON BRITISH CARPET PRODUCTION
}

\section{Hülya KALYONCU'}

\begin{abstract}
The Turkish carpets with a great importance in world's carpet history have their origins in Pazırık Carpet, the world's oldest and the first knotted carpet which was produced by the Central Asian Turks. Carpet tradition of Turks was kept by the Anatolian Seljuk Empire. It had its golden age with the naturalist carpets woven in Bursa and its vicinity in the 16th century that corresponds to the Ottoman period. The Turkish carpets included in the religion and society-thematic paintings made in Renaissance period by the European painters in various countries were regarded as the expression of wealth and magnificence. The Ottoman-Turkish carpets illustrated in portraits of the English aristocrats as well influenced the English carpet art in addition to adding aesthetic values to the paintings. In this study performed in this context, literature of the portraits of English aristocrats that involve Turkish carpets was reviewed. Besides, painters of the paintings, the aristocrat's portrayed and motif-oriented characteristics of the Turkish carpets were addressed in detail. It was aimed to reveal the place of the carpets addressed within the discipline of art history, in Turkish cultural history and their effects on the
\end{abstract}

1 Assoc. Prof. Işı1k University, Faculty of Fine Arts, hulya.kalyoncu@fideltus.com, Orcid: 0000-0002-6325-6009 
Motif-Oriented Characteristics of The Turkish Carpets Illustrated in English...

British carpet production. In conclusion, it was turned out that they place premium on Turkish culture and art.

Keywords: Carpet, Art, Culture, Turkish Carpet, British, Motif

\section{Rönesans Dönemi İngiliz Aristokrat Portrelerinde Betimlenen Türk Halılarının Motifsel Özellikleri ve Halılarin İngiliz Halı Üretimine Olan Etkileri}

\section{Özet}

Dünya halı tarihinde büyük önemi olan Türk halılarının kökeni, Orta Asya Türklerinin üretimi, dünyanın en eski ve ilk dügümlü halısı Pazırık Halısına dayanmaktadır. Türk halı geleneği, Anadolu Selçukluları ile devam etmiş, 16. yüzyıl'da Osmanlı dönemi Uşak ve çevre bölgesi halıları ile zirveye ulaşmıştır. Rönesans döneminde Avrupalı ressamların yaptıkları dini ve sosyal içerikli tablolarda görünen Türk halıları, zenginliğin ihtişamın ifadesi sayılmışlar, İngiliz aristokratlarının portrelerinde tasvirlenen Osmanlı-Türk halıları ise tablolara kattıkları estetik değerler yanında, İngiliz halı sanatına etki de etmişlerdir. İngiliz portre sanatında tasvirlenen Türk halılarının motif özelliklerinin, İngiliz halı sanatına olan etkilerinin saptanmasının amaçlandığı bu çalışmada yöntem olarak, İngiliz aristokratlarının Türk halıları ile göründükleri portre çalışmalarının literatür taramaları yapılmış, tabloların sanatçıları, betimlenen aristokratlar ve Türk halılarının motifsel özellikleri detayları ile ele alınmıştır. Dünya halı sanatına etki eden Türk halı sanatının her yönüyle geliştirilerek yaşatılmasının, Türk kültür ve sanatı açısından büyük önemi olduğu sonucuna varılmıştır.

Anahtar Kelimeler: Halı, Sanat, Kültür, Türk Halısı, İngiliz Halısı, Motif

\section{INTRODUCTION}

The oldest known knotted (Gördes knot) carpet of the Turkish and world carpet history is Pazırık Carpet of the Asian Huns that was found in Pazırık within Altai region of South Siberia in 1947 (Franses, 2007, p.39) and dates back to 3rd2nd B.C. (Aslanapa, 2005, p.16) (Yetkin, 1991, p.6)2. As part of the carpet art which was quite significant among the traditional arts of the Central Asia Turks, carpet production of the Anatolian Seljuk Empire and the Ottoman Empire continued evolutionarily. The carpet art that regularly and systematically progressed from the 13rd century to the 19th century. Moreover, new carpet types were included in production in every period.

\footnotetext{
${ }^{2}$ Rudenko attributed Pazırık Carpet to Scythians and defined its production date as the 5th century B.C. (Rudenko, 1970:342-61).
} 
The earliest information about carpet illustrations is found in the Anatolian Seljuk sources. Abu'l-Fida stated that Turkmen carpets were exported to all other countries in the 13rd century (Aslanapa, 2005, p.59). Furthermore, Marco Polo, an Italian explorer reported during his visit to Anatolia in 1271 that the world's best and the most beautiful carpets were woven in various centers, particularly Konya (Polo, 1955, p.35-37) ${ }^{3}$. It is known that the Anatolian carpets were exported to Iraq, Syria, Egypt, India and China and spread to Europe through Italian merchants in this period (Sönmez, 2006, p.55). Numerous written and visual documents demonstrate the significant demand in Eastern European countries for the Turkish carpets and majority of the carpets indicated in the documents of the 15th and the early 16th centuries have Turkish origin and were made in Ottoman territories (Sherill, 1996, p.16-17).

Similar to the other European aristocrats, portrait making was deemed as a statue symbol by British aristocrats in Renaissance period that greatly contributed to the development of portrait painting and the Turkish carpets started to be included in the portraits of aristocrats and family pictures in the said era (Yetkin, 1964, p.208-222). The mostly depicted typings of Anatolian-Turkish carpets seen in those works are the Seljuk carpets with animal patterns or the Type I small plant-pattern Holbein carpets, the Type II Holbein carpets (Lotto carpets), the Type III large-pattern Holbein carpets, the Type IV.

Large-pattern Holbein carpets and the Ottoman carpets known as the star carpets of the classical period. Besides, it is known that noblemen ordered Uşak carpets with a special emblem after these carpets which were mentioned with the names of the Renaissance painters, Hans Holbein and Lorenzo Lotto due to being illustrated in their works, and most of which were made in Western Anatolia, became pretty well-known in Europe (Atasoy and Uluç, 2012, p.150).

The British source that first described a Turkish carpet is a document written by a person named Antony Querrinus. The document shows the tax exemption for the carpets bought for the high priest of the Monastery of Saint John in 1439. It certifies that Venetian and Genoese merchants bartered Turkish carpets for British wool carpets. According to the document, the Genoese citizen and merchant Antonio Gallio bartered forty of fifty Turkish carpets in 1492, thus, he gained quite high income and even, he returned to London with more Turkish carpets in 1494 (Y1ld1z, 2002, p.574).

\footnotetext{
${ }^{3}$ see: Mills. J. (1975). Carpets in Pictures, London
} 
Motif-Oriented Characteristics of The Turkish Carpets Illustrated in English...

The most important document that proves the presence of Turkish carpets in England is a record that reports the loading of seven "Damascus-Origin"4 carpets exported from Venice on behalf of the potent Cardinal of Henry period (1491-1547), Wolsey. However, as understood based on the records, even this cardinal who was highly influential in that age had to wait for sixty carpets for two years following his order given in 1560 , because of the heavy demand for the said carpets (Sweetman, 1988, p.11). Even though Cardinal Wolsey's carpets were brought from Venice, it is known that the carpets were directly sent to England from East in this period (Y1ld1z, 2002, p.575).

\section{Purpose of the study}

This study aims to;

1. Review the carpets produced on the Anatolian looms within the context of the paintings that portrayed the British aristocrats together with these carpets, and their painters, the aristocrats depicted, and typing and motif-oriented characteristics of the carpets,

2. Discover the effects of the Anatolian carpets on British carpet production.

\section{METHOD}

In the research, the paintings which are exhibited in many museums around the world and in which European painters of the Renaissance depicted the aristocrats and various scenes of different countries with Turkish carpets, and the literary sources were reviewed. The works which are shown in museums and portray the British aristocrats with Turkish carpets were scrutinized. Types of the Turkish carpets classified by periods and patterns were discussed through comparisons and evaluations by using the national and international sources. It was aimed to make definitions within the context of the relationships established between the similar ones.

\footnotetext{
${ }^{4}$ The Damascus-origin defined for the carpets refers to the carpets made in east. It is known that most of the carpets illustrated in the British paintings, especially in the 16the century and at the beginning of the 17th century were made in Anatolia even if all of them were not included (Atasoy and Uluç, 2012, p.207).
} 


\section{FINDINGS AND INTERPRETATION}

\section{The Turkish carpets in the paintings of British Aristocrats}

Several painters who portrayed the British aristocrats with Turkish carpets are William Larkin, Flemish John de Critz the Elder, Van der Meulen and Hans Holbein.

\section{Paintings of William Larkin}

The British painter, William Larkin (1585-1619) made portraits of numerous British noblemen illustrated with the Turkish carpets. Full-length portraits of the noblemen and the Ottoman carpets on which figures were portrayed are seen in most of the forty paintings which were made in around 1615 and attributed to Larkin. It is known that Larkin's portrait works were created in his own atelier by the artists who was working for him, and he topped the paintings off (Hearn, 1995, p.198). Among them, the most famous works of the artists currently known as Redlynch long Gallery series are seven full-length lady portraits (Sweetman, 1998, p.14).

\section{Portrait of Lady Carry}

Rochford Viscountess Dorothy St. John, Lady Carry is one of these seven noble women. In the painting, Lady Cary stands on a stylized Ming carpet with animal patterns (Sweetman, 1998, p.15). The carpet features the animal illustrations in which they fight with the filled geometric sections. The depicted animals are subject to stylization. Such carpets were first seen in the paintings of European painters and their original versions were scarcely revealed. Patterns of the carpets whose greater part is in pieces could be completed and dated by means of these depictions (Aslanapa, 2005, p.65). This carpet group called Ming carpet due to first being found in a church in central Italy is the first group that was determined within the animal patterned carpet group.

Examples with similar patterns for the carpet in the painting are exhibited at Berlin Staatliche Museum, Stockholm, Konya Mevlânâ Museum and İstanbul Carpet and Rug Museum today. In Ming carpet shown at the Museum of Islamic Art, the pattern of dragon-phoenix fight seen within the octagons which divide the carpet into two from the middle has a pretty large size. Head of the phoenix is hook-shaped and its tail is completely cut. On the other hand, it is observed that the dragon pattern was minimized considerably and its motif-oriented characteristics are quite simple. Yellow, red and blue patterns are placed in the hexagons with black background. It was surrounded by a narrow rim. The animal 
Motif-Oriented Characteristics of The Turkish Carpets Illustrated in English...

patterns in the carpet whose only three modules can be seen do not resemble any pattern in the familiar carpets. This carpet pattern frequently included in the paintings of the 15th century prove the export of carpets from Anatolia to Egypt and Europe (Aslanapa, 2005, p.73).

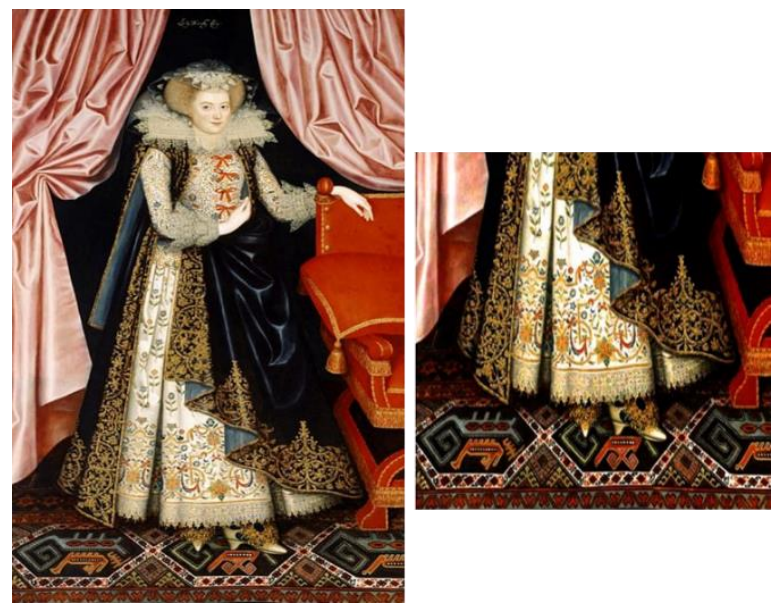

Figure 1. William Larkin, Rochford Viscountess, Dorothy St. John, Lady Carry portrait, about 1615, Kenwood House, London.

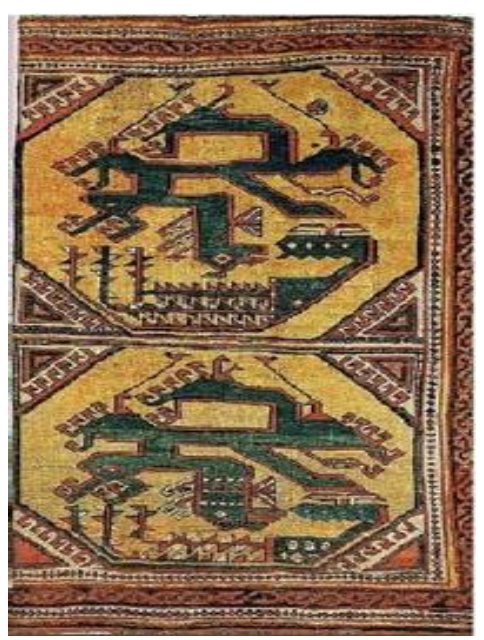

Figure 2. Ming Carpet, the second half of the 15 the century, $1.72 \times 90 \mathrm{~cm}$. Berlin, Staatliche Museum, Berlin, inv no.I.4. 


\section{Portrait of Catherine Knyvett}

Another noble woman and carpet-themed painting attributed to Larkin is the portrait of Catherine Knyvett (1564-1638). Knyvett is the countess of Suffolk and served to the Queen of Scotland and England, Anne of Denmark (Payne, 2004). The countess was portrayed on a Western Anatolian carpet with Type IIIHolbein (Bergama) pattern that consists of the stars in octagons. Type III Holbein carpets were made in Bergama region (Yetkin, 1964) and included in the European paintings from the second half of the 15th century. They feature octagonal or diamond-shaped geometric and abstract plant patterns that are placed in the square or rectangular sections and replace the animal-patterned Seljuk carpets. Corners of the main rectangles were shaped with triangular details (Erdman, 1957, p.25-32). These carpets produced in four different categories are actually the early Ottoman carpets and are called Holbein Carpets in world carpet literature, because they were illustrated in paintings of the German painter, Holbein for many times (Aslanapa, 2005, p.107).

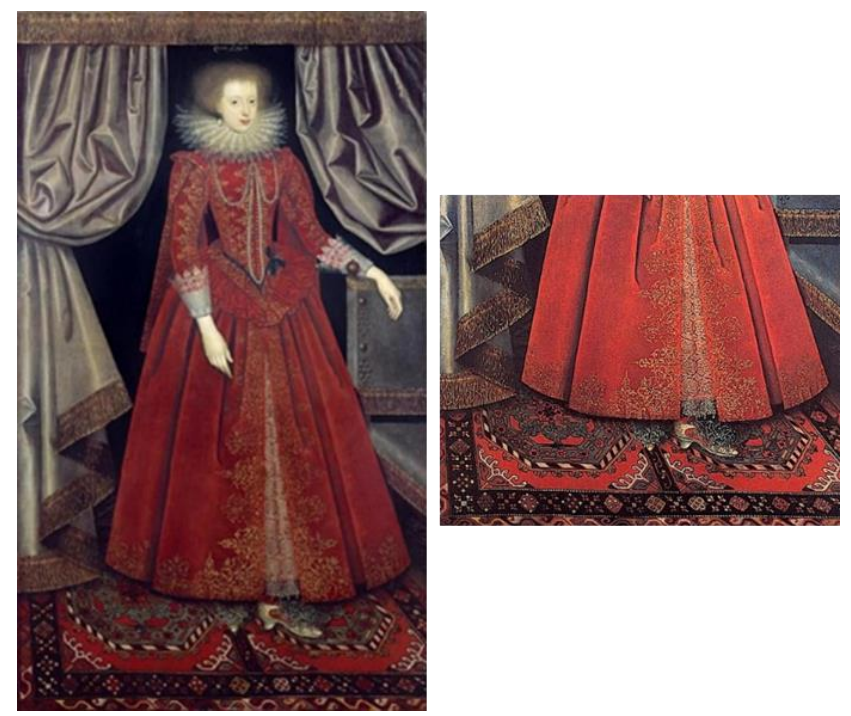

Figure 3. William Larkin, portrait of Catherine Kneyvett on Holbein Carpet, 1615, Kenwood House, London. 
Motif-Oriented Characteristics of The Turkish Carpets Illustrated in English...

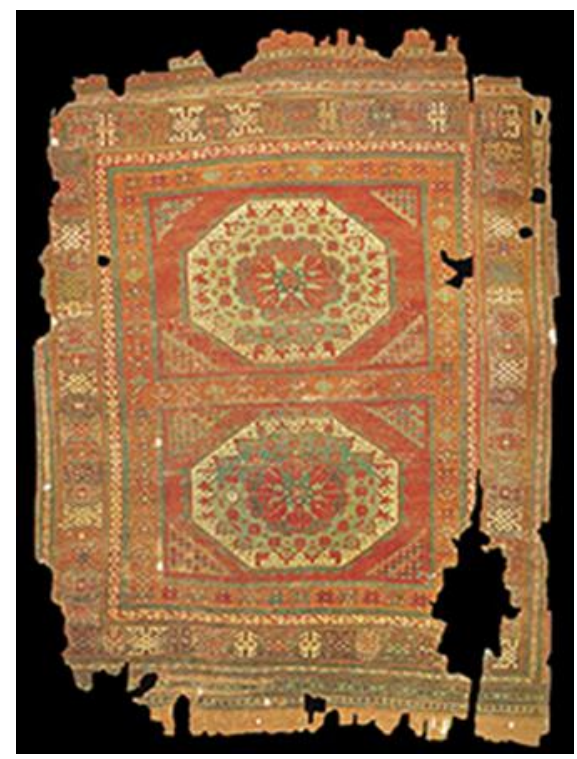

Figure 4. An early Ottoman carpet made in the 15 th century, Museum of Turkish and Islamic Arts.

\section{Portrait of Richard Sackville}

Another painting attributed to Larkin is the portrait of Sir Richard Sackville (1507-1566), a member of English parliament. In the work, Sackville was portrayed on a Lotto carpet. It is a Type II Holbein carpet in which abstract plant patterns completely replace geometric patterns as ornament composition. In such carpets, patterns and non-contour octagons are bound to four-arm diamonds via fine rumis and palmettes. In fact, Holbein never depicted such patterned carpets. They were often used in paintings by the Venetian painter, Lorenzo Lotto. For this reason, these carpets have been named Lotto Carpets in recent periods as well. The carpets first seen in the works of European painters were included in the British painting from 1520.

As understood based on the researchers conducted in the next periods, they were definitely made in Uşak (Yetkin, 1964). Such carpets whose examples were newly seen at the end of the 16th century disappeared in a while at the end of the 17 th century. This carpet type allowed for the switch to Uşak carpets. 

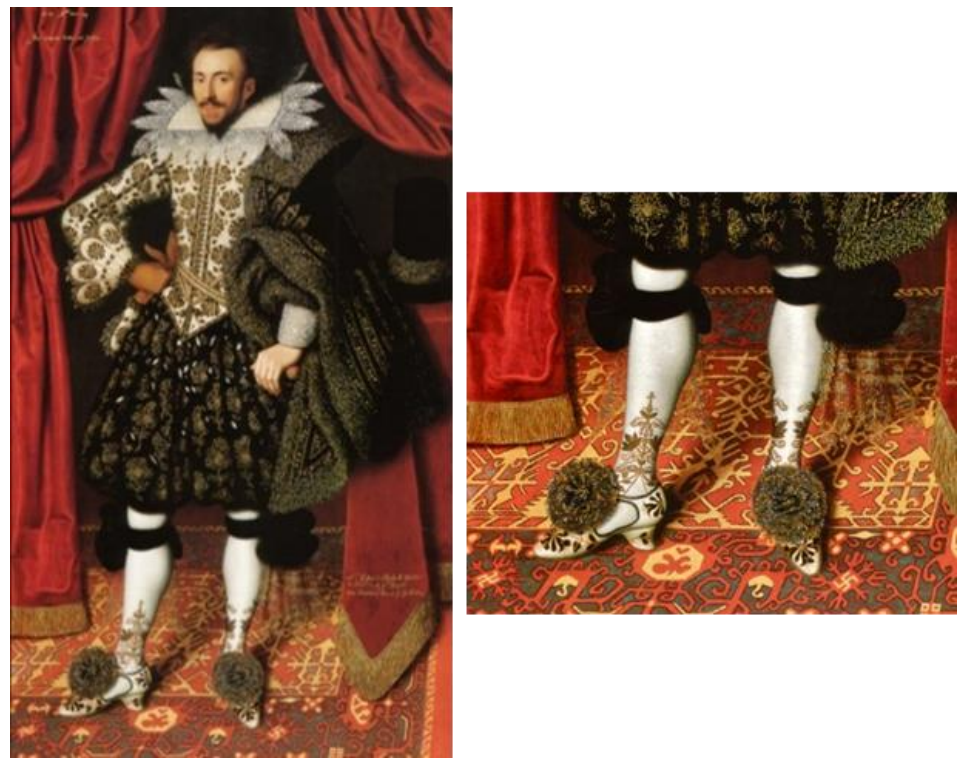

Figure 5. William Larkin, portrait of Richard Sackville on Lotto or Type II Holbein Carpet, 1613, Kenwood House, London.

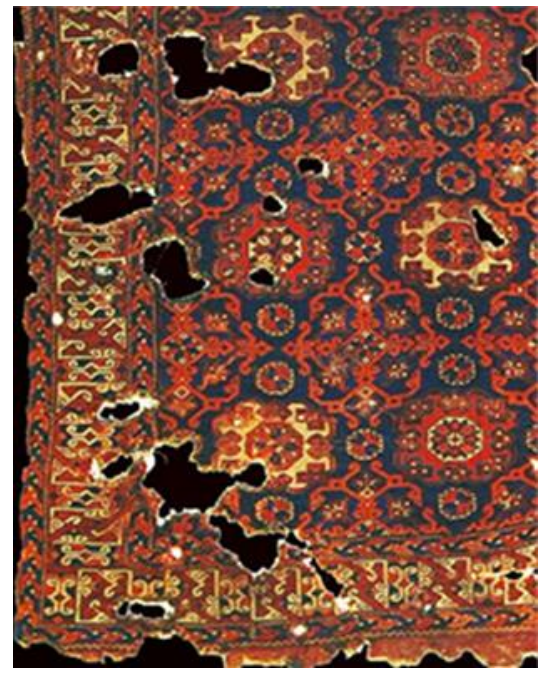

Figure 6. An Ottoman carpet of the 15th or 16th century, the Ethnography Museum of Ankara. 
Motif-Oriented Characteristics of The Turkish Carpets Illustrated in English...

\section{Paintings of young Hans Holbein and his ecole}

The German painter Hans Holbein (1497-1543) accepted as one of the primary portrait painters in Renaissance (16th century) gained recognition with his portraits in which he illustrated Henry VIII, King of England from the Tudor Dynasty and court circle with a realist touch.

Holbein who brought a new mentality to portrait making by detaching appearance of the portrait within composition and scene in the general painting sense from general composition is known as an artist who popularize the portrait art. The artist came to English palace in 1526 upon the suggestion and letter of recommendation of Erasmus, the great scholar from Rotterdam. He was just 29 years old in that period. The Flemish and Dutch painters who had low income and low status despite working in the court up to this age gained value with the portrait art developed by Holbein and pioneered the British painters in this regard as well (Fawcett, 1998-2001, p.156). One reason that lies behind such a considerable increase in value of Holbein's portraits is the significance of the Turkish carpets used in the works by him. The Ottoman carpets traditionally included in the portraits and compositions by Holbein started to be mentioned as Holbein carpets in literature. Several painters after Holbein who followed his ecole maintained this tradition. In this period, the British people began to produce carpets although they adopted the production of finely-processed carpets rather than that of the knotted carpets. Furthermore, it is known that the painter Lorenzo Lotto who often used the Ottoman carpets in paintings had a high chance to see these carpets in the said period which witnessed a dense carpet trade between Venezia and Ottoman Empire.

\section{Portrait of Henry}

The abundance of carpets owned by Henry VIII is noteworthy, considering the good lists and the carpets depicted in the personal and family portraits of the members in Tudor dynasty. Holbein the Younger and his followers made numerous paintings in which Henry VIII was illustrated while standing on the Anatolian carpets (Sherrill, 1996, p.21). Henry known to dote upon the Ottoman clothes and carpets is recognized as a nobleman who first started the tradition of portraits that depicted Turkish carpets. John Mills stated that Henry got 13 portraits in this composition made. Most of them were created at the Whitehall Palace in 1537 by Hans Holbein. Nevertheless, several portraits were reduced to ash in a fire breaking out in 1698, and shown on fresco. Moreover, it is known that the king was taking 65 Turkish carpets with one in his travels (Maclean, 2009). 
Four hundred carpets were recorded in Royal inventory as Lotto and Holbein carpets or Uşak carpets both in 1547 during the period of Henry and after that date. Some of these recorded carpets are seen in portraits of Henry VIII, Edward VI and noblemen (Fawcett, 2001, p.155). In one portrait, Henry VIII was depicted standing on a Type IV Holbein carpet. The big square filled with octagon in center is the main pattern in this carpet type. The octagon is stuffed with spiral stars. Small squares adorned with octagons inside are seen below and above the squares. Several carpets feature braided kufic borders.

A different carpet group that pretty resembles Type IV Holbein carpets is known contains Mamluk carpets. It is understood according to several published sources that they are confused. Such carpets have single knots and small plant patterns. However, their composition characteristics are Turkish-origin and it was acknowledged that these carpets were generally produced by the masters based on Mamluk tradition (Aslanapa, 2005, p.150).
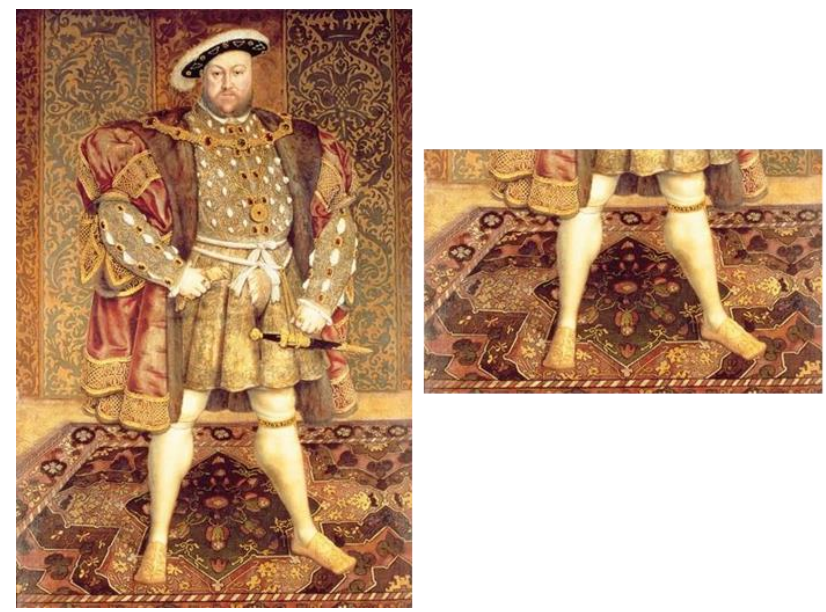

Figure 7. Hans Holbein the Younger (1497/98-1543), portrait of Henry VIII (1491-1547), 150x $221 \mathrm{~cm}$, oil painting, Belvoir Castle, London. Peter Johson Fine art. 


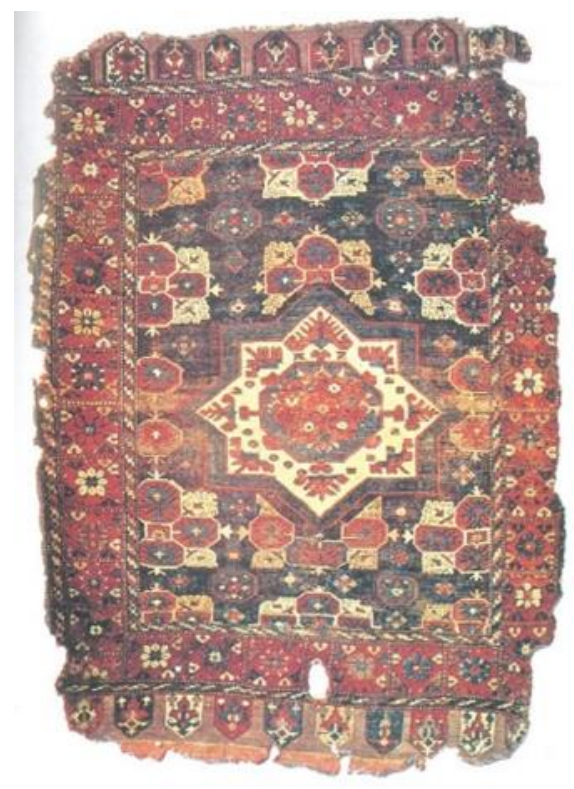

Figure 8. Holbein type carpet, 18 th century, $1.70 \mathrm{cmx} 1.32 \mathrm{~m}$. İstanbul, Museum of Turkish and Islamic Arts.

\section{Paintings of Lucas de Heere}

Lucas de Heere (1534-1584), one of the Flemish artists who is painter, poet and author portrayed Henry VIII and his children with an allegorical expression. In the painting, Henry VIII sits on his throne and passes the sword of justice to his son Protestant Edward VI, heir to throne. It was made by the artist when he came to London from Ghent. On the left are Catholic Mary who is Catherine of Aragon's daughter, and Mary's husband and King of Spain, Philip II are seen in the painting. In the artwork, Anne Boleyn's daughter, Elizabeth who would come to the throne as Elizabeth I is on the right next to Mars, god of war with a shield on the ground. The painting commissioned by Queen Elizabeth as a gift for Sir Francis Walsingham aims to show the peak point and power of the Tudor Dynasty, using allegorical expression which is one of the basic features of the Renaissance painting in the 16th century (Hearn, 1995, p.81-82). (Strong, 1969, p.158).

The carpet depicted in the painting is a Medallion Uşak carpet. Different from Holbein carpets with geometric patterns, the medallions completely filled with plant patterns and rumis make up the main pattern of this carpet type. Considering that use of the medallion pattern which comes to carpet art from 


\section{Hülya KALYONCU}

Persian ornamentation commenced from the 16th century, start date of Uşak carpets can be thought as the first half of the 16th century. In center of the pattern, there is a large circle medallion next to the medallion variants with sharp edge. Even though the composition points out to infinity, it is different from the Persian medallion carpet examples with respect to pattern mentality. They were produced from the 16th century to the 18th century (Aslanapa, 2005).

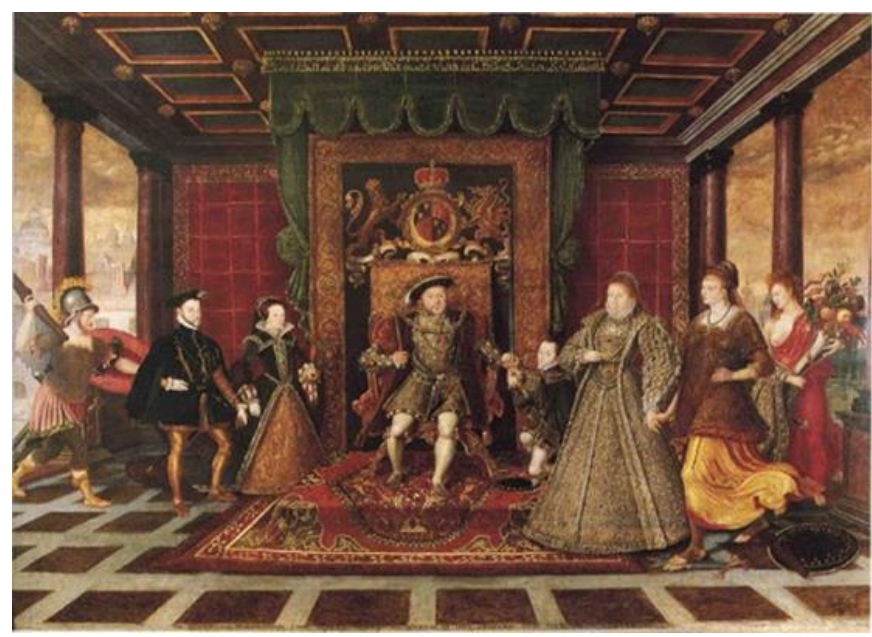

Figure 9. Lucas de Heere, allegorical painting of Henry VIII with his children, (Mary I and Philip II of Spain, Henry VIII, Edward VI and Elizabeth I), 1590, 131.2 x $184 \mathrm{~cm}$ Sudeley Castle. Gloucestershire, National Museum Cardiff. 


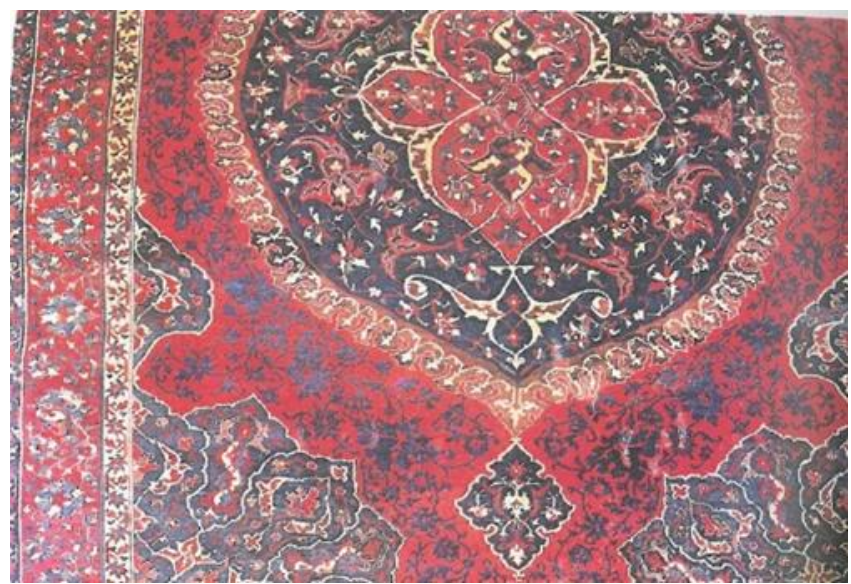

Figure 10. Medallion Uşak carpet, London, Victoria and Albert Museum.

\section{Paintings of John de Critz the Elder}

\section{Somerset House Conference Painting}

Critz, the Flemish artist known as John de Critz the Elder (1551-1642) worked as the assistance of Lucas de Heere until the 1590's. Later, he was active at the royal court during the reigns of James I of England and Charles I of England.

In "Somerset House Conference" Painting that illustrates the end of nineteen-year Anglo-Spanish war, and the peace treaty signed with Spain in 1604 within the period of James I, English and Spanish delegates seated around a long table are shown (Atasoy and Uluç, 2012, p.210). Even though the painter is a matter of debate, it is accepted that Critz worked on this painting and it belongs to Critz's atelier (Ungerer, 1998, p.173). The person sitting on the front right side is Robert Cecil who drew up the treaty and would be the 1st Earl of Salisbury later (Ungerer, 1998, p.154).

The table in the center of the artwork is covered with a small pattern Holbein carpet which is quite large. Motif-oriented characteristics of these carpets known as Type I Holbein (or Bergama) or small pattern carpets are as follows: carpet space is divided into small squares or medallions; the center is constituted by the squares made up of octagons and corners of each square pattern is formed through the combination of quarter-sized diamonds. Contours of the octagonal patterns compose of knot-shaped stripes and there is a small octagon 


\section{Hülya KALYONCU}

with eight-star filling in the center. Such type of carpets maintain the traditional production technique of Seljuk carpets for their advanced braided kufic borders. Background of the carpet is blue and red. Green is rarely seen. These carpets actively produced between the 15th and 16th centuries prepared the transition to classical era. Their production diminished following the 16th century and disappeared in the 17th century (Aslanapa, 2005, p.112).

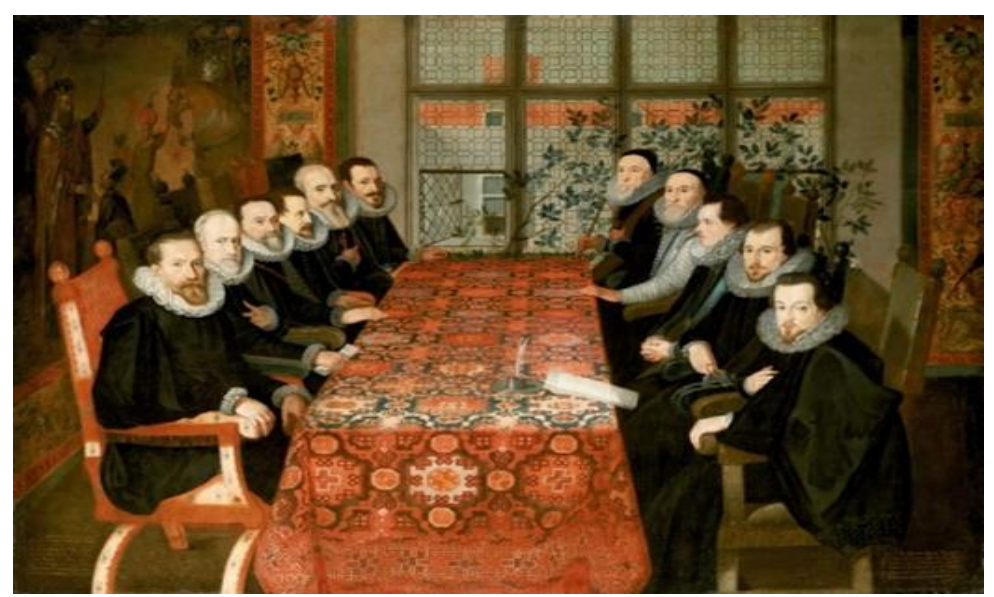

Figure 11. Somerset House Conference, London Treaty, anonymous, 1604, National Portrait Gallery, London.inv. no.665. 
Motif-Oriented Characteristics of The Turkish Carpets Illustrated in English...

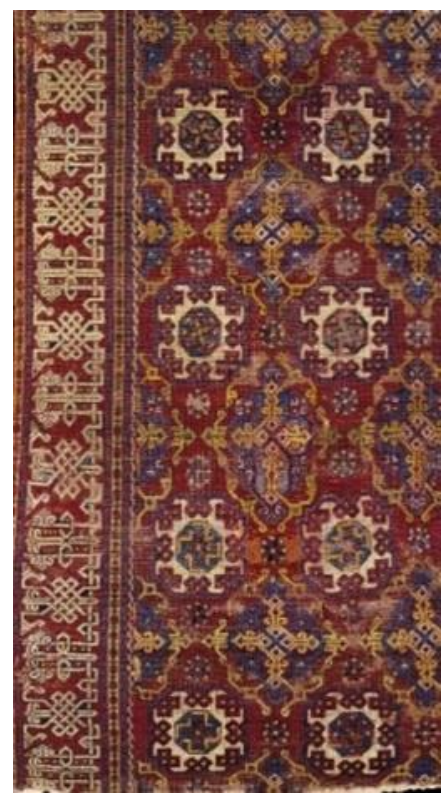

Figure 12. Carpet: Type I small pattern Holbein Carpet, Anatolia, 15th16th Century, Berlin Museum, Düsseldorf, inv.no: I 6737.

\section{Portrait of Thomas Sackville, 1st Earl of Dorset}

English statesman, 1st Earl of Dorset, Thomas Sackville de (1536-1608) is one of the English aristocrats depicted with a Turkish carpet by John de Critz the Elder. In the painting currently exhibited at the National Portrait Gallery in London, the Earl being presented petitions by his secretary, John Suckling was illustrated (Strong, 1969, p.260). Sackville wears the Order of the Garter on his neck and holds a wand. Type of the carpet on which the Earl stands is Lotto carpet. In the carpet, patterns and non-contour octagons are bound to four-arm diamonds via fine rumis and palmettes. Besides, the toothed triangles seen at the bottom and at the top are the new patterns of that era used in the production of these carpets. 
Hülya KALYONCU

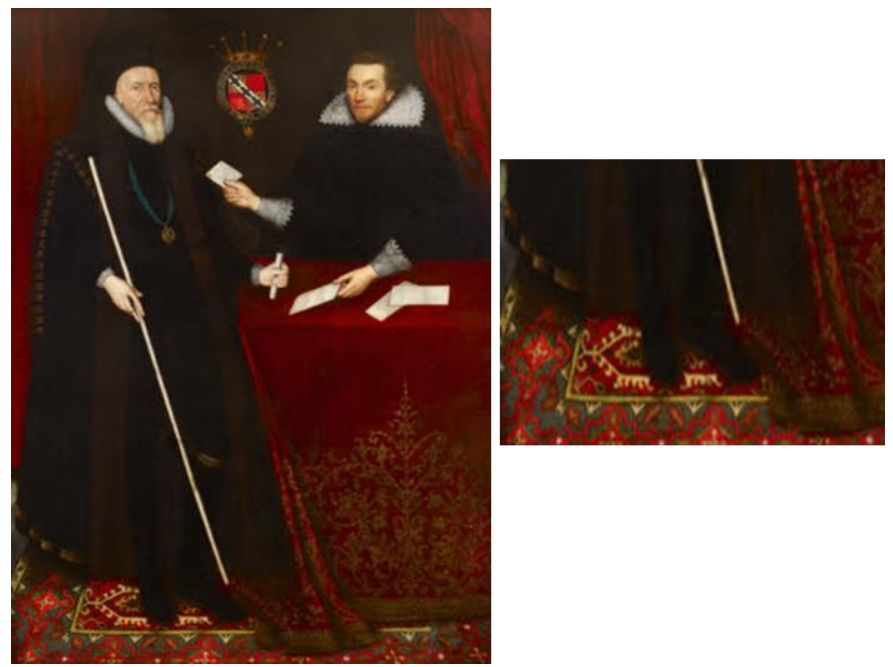

Figure 13. J. de Critz the Elder. Thomas Sackville, 1605-1610, oil on canvas, 2100x1600x30 mm, Sissinghurst Castle, Kent. National Portrait Gallery, London.

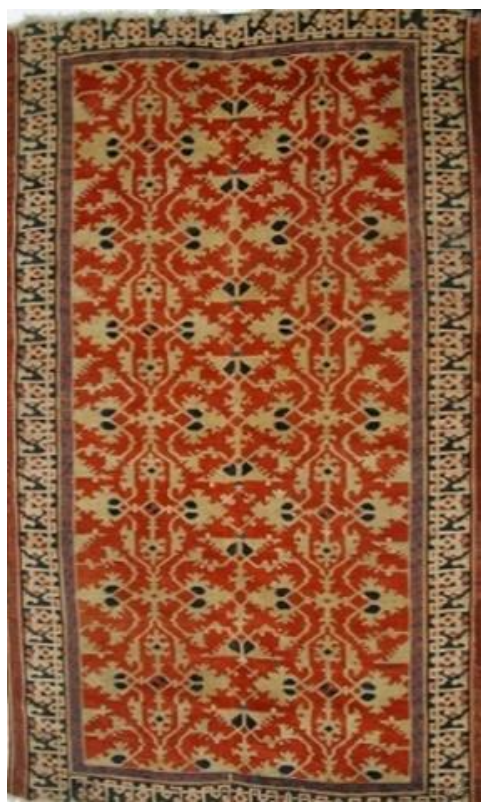

Figure 14. Lotto carpet, 16th century, $217.2 \mathrm{~cm}$ x130.2 cm. Metropolitan Museum, New York. 


\section{Paintings of Steven van der Meulen}

The Flemish artist Steven van der Meulen (1543-1563) who is famous with his portraits, hunting illustrations and landscape paintings He worked as a painter active at the court during the reign of Elizabeth I. Meulen made innovative portraits of the queen as "Barrington Park" type called by Sir Roy Strong (Strong, 1969, p.119). Thomas Platteri who visited the court of Elizabeth I known with her interest in Turkish carpets told while describing the throne room that the knotted Turkish carpets were rolled out only in front of the queen's throne and on the way going to the throne (Yild1z, 2002, p.575).

In Meulen's Hampden portrait of Elizabeth I, border of a Type II Holbein carpet/ Lotto carpet under large skirt of the queen is seen. Plant patterns are dominant in the carpet with a red background. Contours in borders are completely unclear. Octagons and four-arm diamonds are bound to each other with rumis and palmettes.

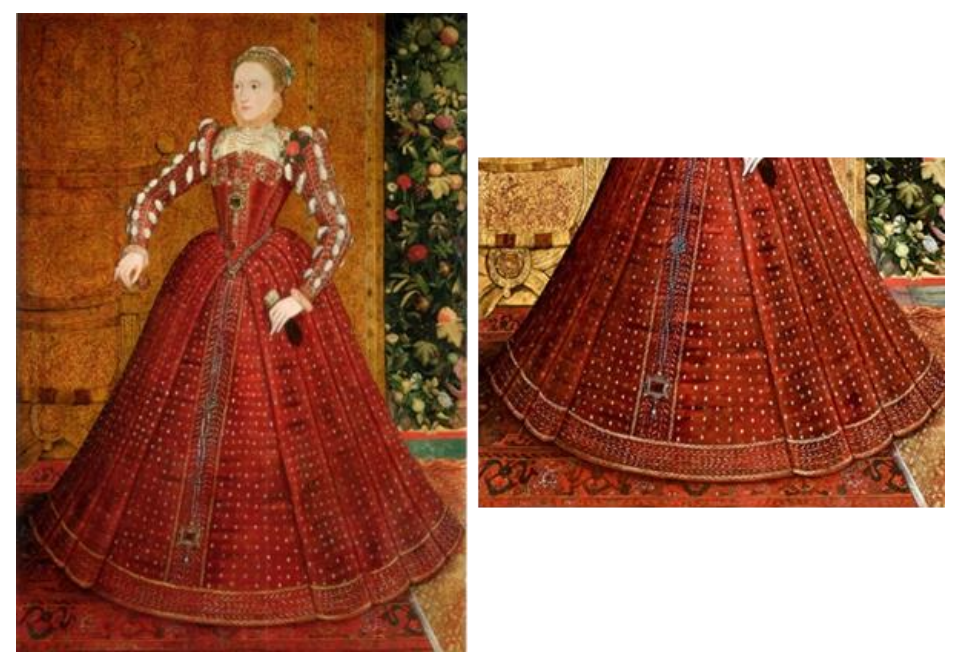

Figure 17. Steven van der Meulen. 1567, Queen Elizabeth I. The Hampden Portrait, oil on-canvas painting, $196 \mathrm{cmx} 140 \mathrm{~cm}$. Special collection. 


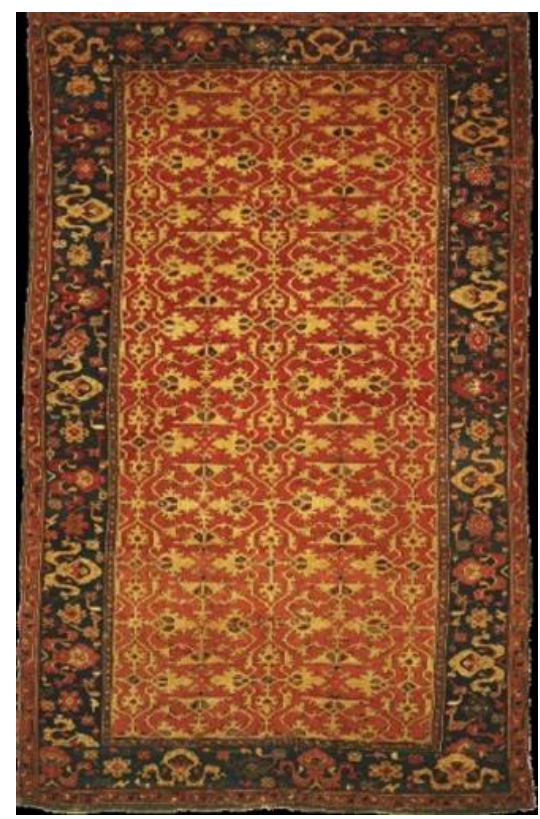

Figure 18. Lotto carpet, Uşak, the second half of the 16th century, Philadelpia Museum of Art.The Joseph Lees William Memorial Collection.

\section{Paintings of Remigius van Leemput}

Remigius van Leemut (1607-1675), the British artist of Flemish origin who is in the ecole of Hans Holbein the Younger portrayed Henry VII, Elizabeth of York, Henry VIII and Jane Seymour in front of the wall of the Hampton Court Palace (Jeffree, 2014). The artwork is a copy of a lost painting made by Hans Holbein. Van Leemput was paid $£ 150$ for making the painting and made another copy for Pertworth House in 1669. Nevertheless, both copies of the artwork were burned out in a fire which broke out in 1698. Information regarding these paintings are given in the list of Hans Holbein's works (Jeffree, 2014).

In the painting, the royal family is depicted on a Type I Holbein carpet. In pattern composition of the carpet, background is divided into small squares and each square is filled by octagons. The motif that forms via the merge of each square and quarter-sized diamonds in the corners makes up the main pattern. Contours of the octagons compose of knot-shaped stripes and there is a small octagon with eight-star filling in the center. Background is colored blue and red. 
Motif-Oriented Characteristics of The Turkish Carpets Illustrated in English...

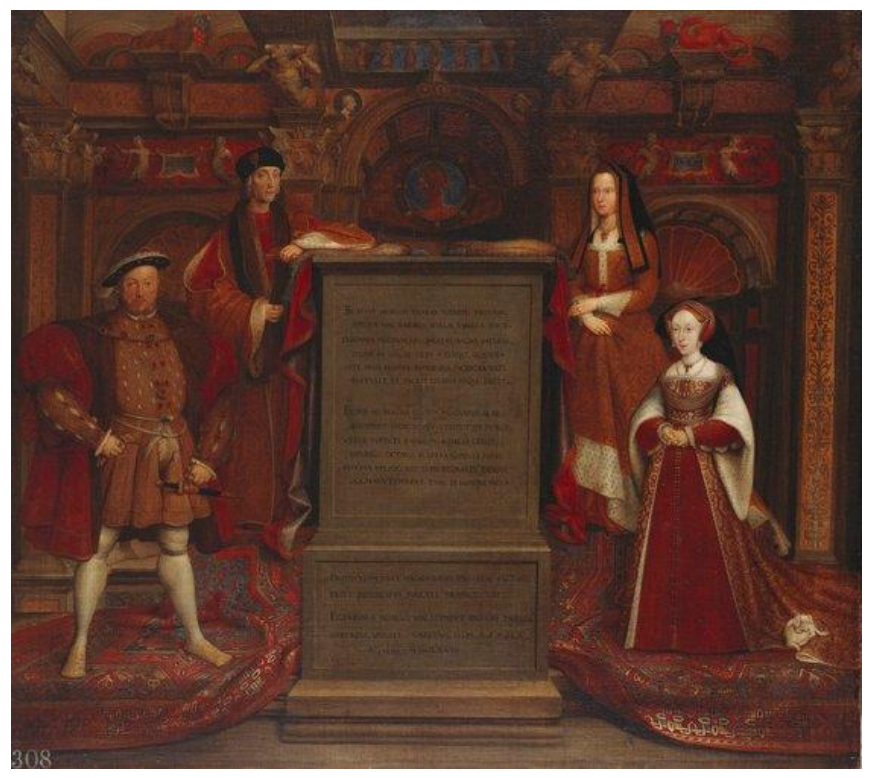

Figure 19. Ecole of Hans Holbein the Younger (1497/-around 1543), Henry VII, Elizabeth of York, Henry VIII and Jane Seymour, 1667, oil on-canvas painting, 88.9 x99.2 cm., Royal Collection, Hampton Court Palace, inv no: 4/137.

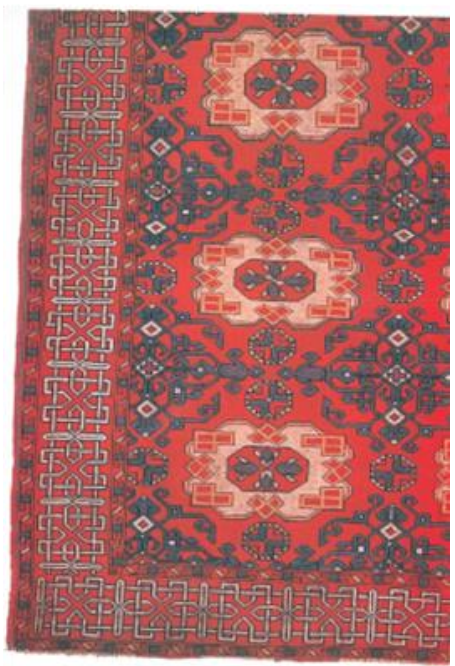

Figure 20. Type I Holbein Carpet, the end of the 16th century. 


\section{Paintings of Daniel Mijtens}

Early paintings of the British portrait painter of Dutch origin, Daniel Mijtens (1590-1647/48) are lost (Murray, 1996, p.364). He portrayed majority of the court circle during the reign of Charles I of England and brought a different naturalist approach to British court portraits. Several artworks of the painter are exhibited in the Royal Collection. The artist made paintings of James IV of Scotland, Margaret Tudor and Queen of Scots, Mary (Devon, 1836, p.350-358).

\section{Painting of Queen Margaret Tudor}

In a portrait, Mijten depicted Margaret Tudor (1489-1541), the daughter of Henry VII and the Queen of Scotland (Nicolas, 1830, p. 86) wearing ceremonial outfit and standing on a Type II Holbein or Lotto Carpet. In respect to patterns of the red-background carpet, contours of the octagons completely faded away and four-arm diamonds are bound through fine rumis and palmettes. Border of the carpet features that large hatai patterns are bound with the branches bended towards each other and plant stems.

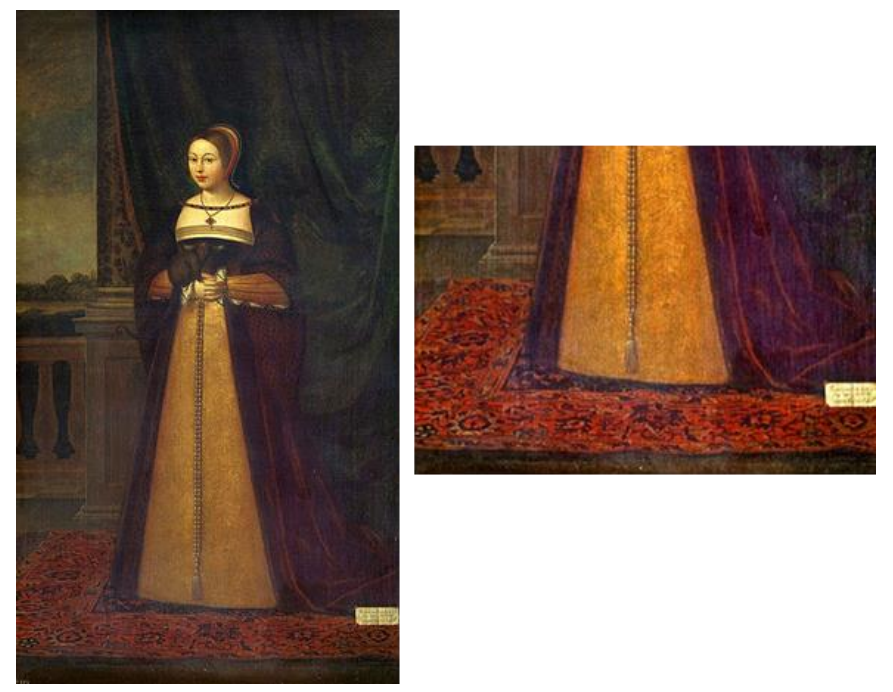

Figure 21. Daniel Mytens, Margaret Tudor, 1620-1638, Warwick Shire Hall, $238.8 \mathrm{cmx} 141.3 \mathrm{~cm}$. Royal Collection. 
Motif-Oriented Characteristics of The Turkish Carpets Illustrated in English...

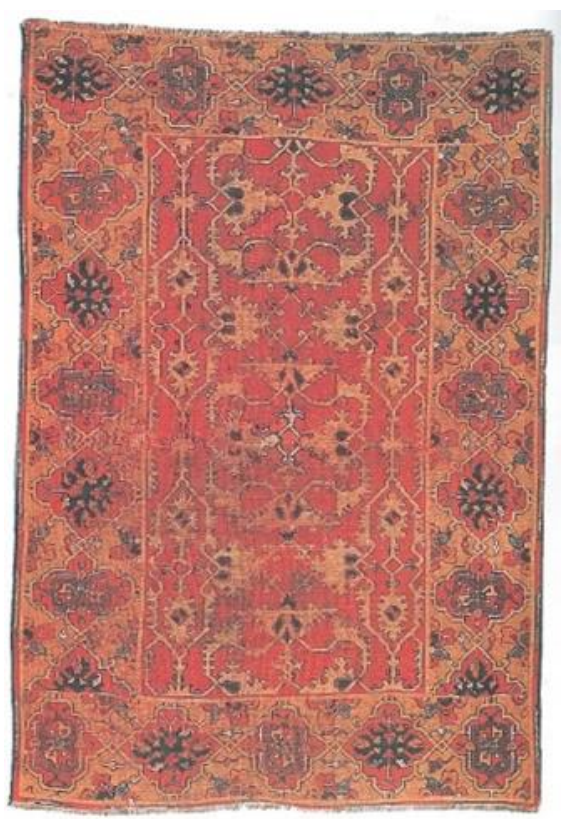

Figure 22. Lotto Carpet, 17th century.

\section{Painting of James, I of England}

Another artist who portrayed James I of England and James VI of Scotland is Daniel Mijtens. In Mijten's painting, the King sits on a red velvet armchair in a room with the floor covered by red-background Type I Holbein carpet. Patterns of the carpet are stylized and small naturalist motifs. 

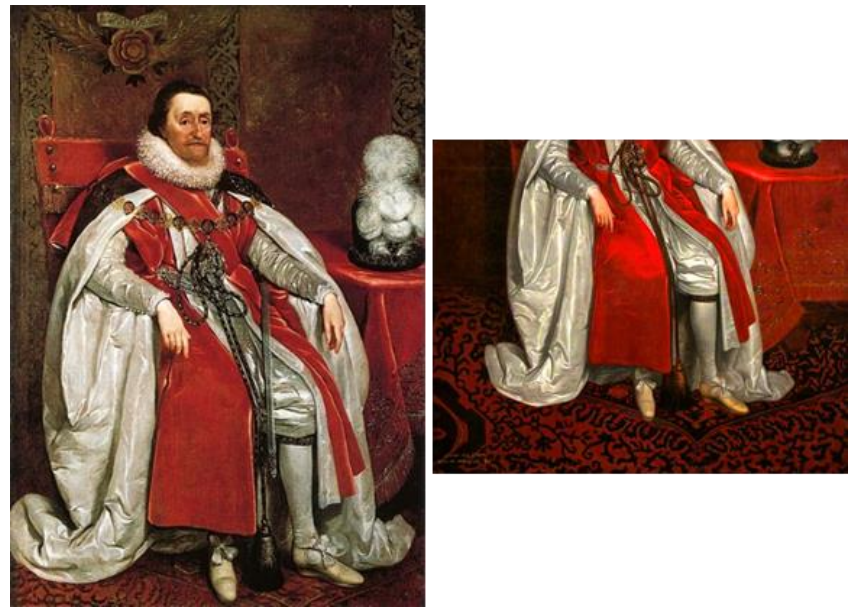

Figure 23. Daniel Mijtens. James I of England James. 1621, oil on-canvas painting, $148.6 \mathrm{~cm}$. x100.6 cm., Knole Sevenoaks, Kent, National Portrait Gallery, London.

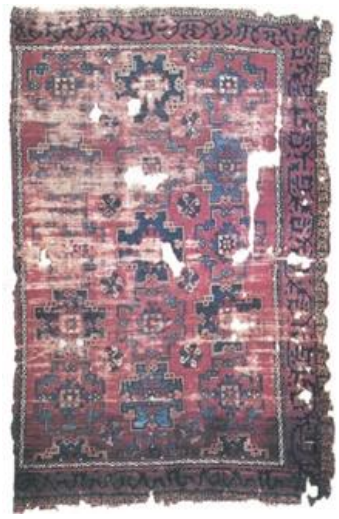

Figure 24. Type I Holbein red-background carpet, İstanbul Vakıflar Carpet Museum.

\section{Painting of Charles Howard}

Charles Howard (1536-1624), 1st Earl of Nottingham is one of the substantial admirals during the reign of Queen Elizabeth I and James I of England and commanded the English fleet in Anglo-Spanish war (Robert, 1970).In Mijten's portrait of Howard, patterns of the carpet which covers the table on the left of Howard feature the motifs used in a Bergama prayer rug. In Bergama prayer rugs produced in the 17 th century, the stripe that surrounds the 
Motif-Oriented Characteristics of The Turkish Carpets Illustrated in English...

main area of the rug and turns into a bow above and a keyhole below makes up the niche. It has a border with ribbon cloud pattern. The niche pattern on the carpet represents the niche-Qibla wall at mosques. The flowers dangling from the sharp edge of the bow symbolizes the kandil that refers to God. For some people, the small keyhole pattern below is the symbol of the legendary mountain in ancient China. According to other people, it is only the repetition of niche, even the path going to tomb. Many researchers suggest that this pattern represents the water chamber used for performing ablution, and the canal which drains water away. Since the style of rumi-patterned central medallion and border pattern is linked to Uşak ateliers, such prayer rugs were formerly attributed to Western Anatolia. Nevertheless, today, it is associated with the keyhole group in various regions of Anatolia, particularly in central and southern Anatolia.

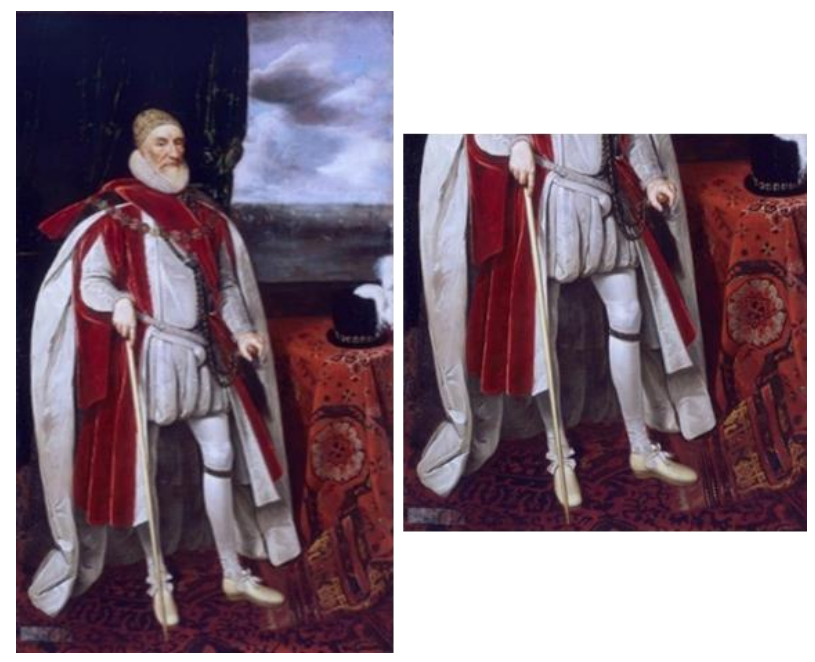

Figure 25. 1620. Daniel Mijtens. Charles Howard, 1st Earl of Nottingham. National Maritime Museum. 


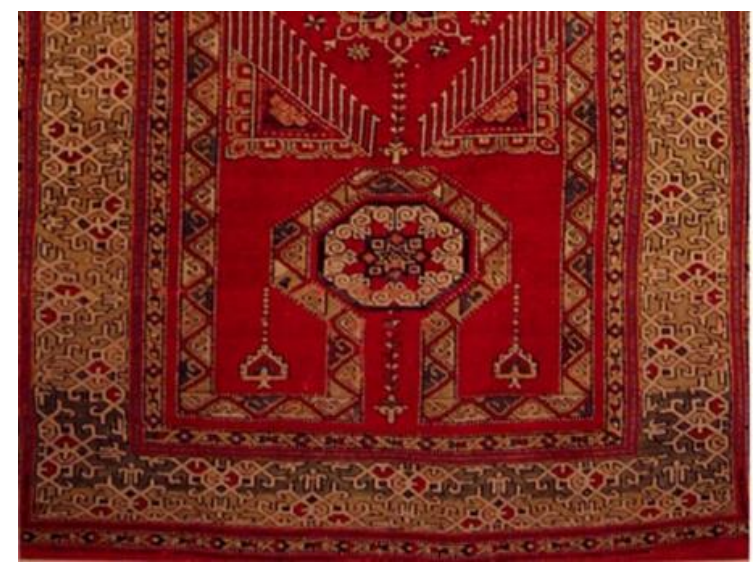

Figure 26. Bergama prayer rug, 15th-16th century. Topkap1 Palace.

\section{Paintings of Paulus van Somer}

The painter Paulus van Somer (1577-1621) is a Flemish artist who came to England from Antwerp during the reign of James I of England. He became one of the leading artists of the court. He made portraits of many aristocrats, especially James I and Anne of Denmark. It is known that Daniel Mytens followed Sommer's ecole (Cerasano and Davies, 1996, p.54).

\section{Painting of Henry Hastings}

In a painting of Paulus von Somer, the portrayed person, 5th Earl of Huntingdon Henry Hastings stands on another group of Turkish carpet type originating from Uşak which is named Bird or Çintemani. Background of this carpet group is colored white or creme and contains Chinese cloud patterns. Its borders have palmette. It is thought that the said carpets were manufactured between the first half of the 16th century and the mid-17th century (Aslanapa, 2005, p.194).

Composition of the carpets called bird for including a pattern that reminds of a bird as the main motif at first glance is misleading, because it actually consists of a background in various colors between two opposite leaves. Patterns are completely based on leaves and the motifs are placed between rosettes and flowers. "The Bird-Uşak carpet" which is a classical Anatolian carpet type is seen in this painting made in 1601 is probably the first and the only one artwork created by a European painter. 
Motif-Oriented Characteristics of The Turkish Carpets Illustrated in English...
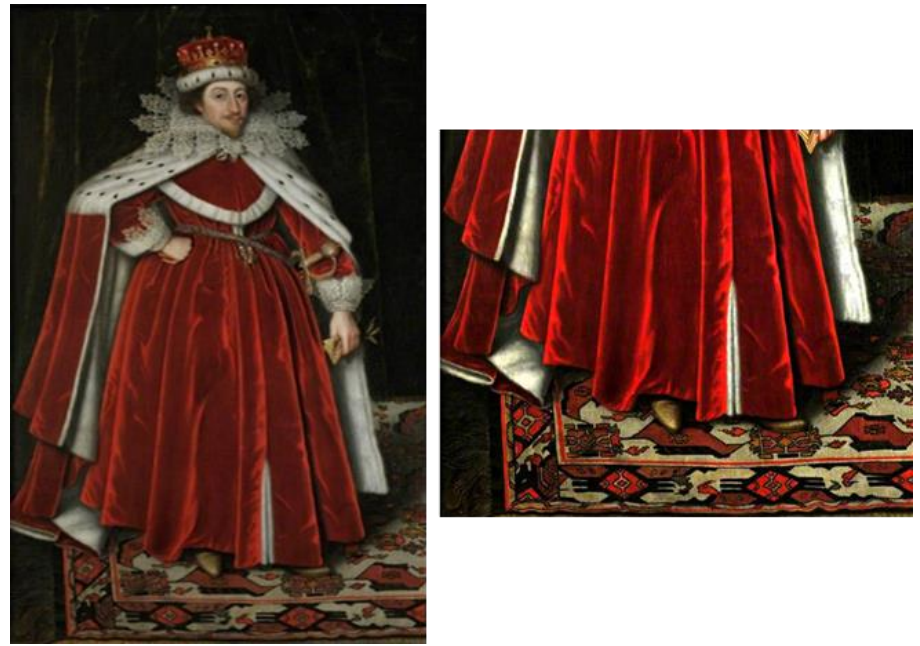

Figure 27. Paul van Somer. Henry Hastings, 3rd Earl of Huntingdon. 1601, oil on-canvas painting, 207 x $120.7 \mathrm{~cm}$. Queens College, Cambridge Univ.

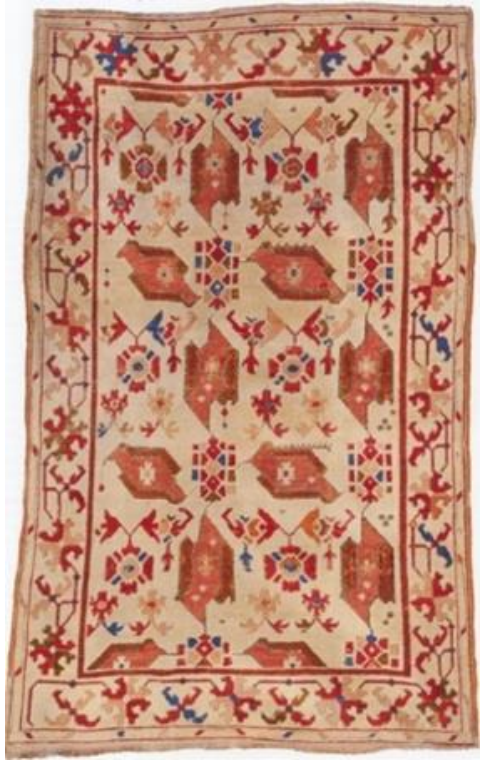

Figure 28. Bird-Uşak carpet, 17th century. 175X108. Museum of Turkish and Islamic Arts. 


\section{Paintings of Peter Lely}

Sir Peter Lely (1618-1680) of Dutch origin served to English court for a long period of his art life. The Princess of England, Henrietta Anne (1644-1670) portrayed by Lely is the youngest daughter of Charles I of England, Scotland and Ireland and Henrietta Maria of France. The princess who went to palace of her cousin, Louis XIV in France when she was three years old married Philippe I, Duke of Orléans and her other cousin. The painting was offered to Charles II as a gift in 1672 (Mills, 1975).

The artist (1618-1670) depicted an Anatolian carpet that is mentioned with the name Transylvanian carpets in literature. Although the Transylvanian carpets also called as Erdel carpets were woven in Western Anatolia from the 15th century to the 17th century, they take the former name for being present in the Transylvanian churches. General characteristics of these carpets which were woven in Western Anatolia and exported to Europe are similar to those of the carpets of Kula, Gördes, Lâdik and Bergama origin (Aksoy, 2020, p.211-233).

The carpet illustrated in the painting resembles double-niche medallion Transylvanian carpet. In this carpet type, a composition which consists of geometric and plant-based motifs is placed in a somewhat large medallion. Motifs of this medallion is a follow-up of the Starred Uşak medallions. It has three borders one of which is large. The other two borders are narrower. A pattern integrity that is made up of cartridges or the naturalist plant-based motifs applied geometrically is seen in large border of the carpet. Background of the carpet is filled by the patterns in which quinary tiny motifs and tulip, leave and clove motifs make up an integrative composition. Some fields of the medallions consist of diamond shaped motifs that are formed by flowers and bound to each other with leaves and branches. In addition to typical double-niche examples for Transylvanian carpets, traditional single-niche versions were rarely woven. 
Motif-Oriented Characteristics of The Turkish Carpets Illustrated in English...
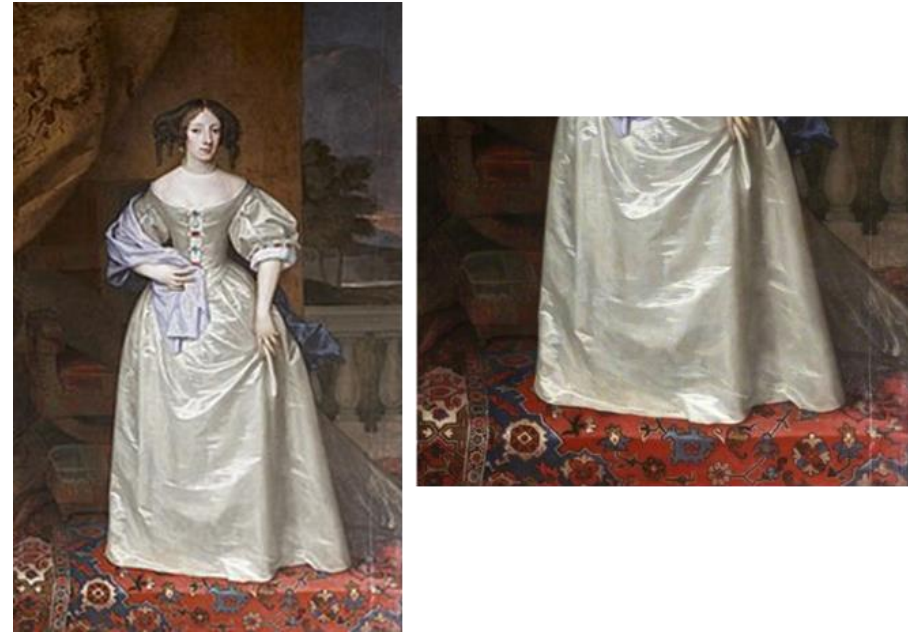

Figure 29. Peter Lely, Princess Henrietta Anne, daughter of Charles I of England, oil on-canvas painting, $254 \mathrm{~cm} .137 \mathrm{~cm}$., Exeter Guildhall.

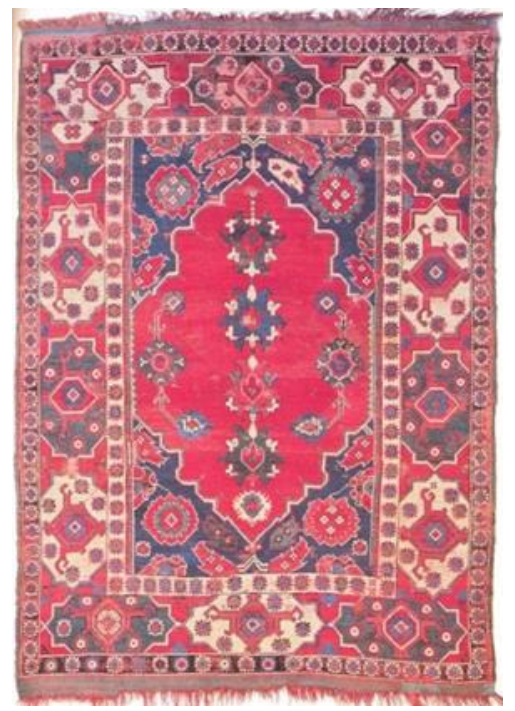

Figure 30. Transylvania Uşak. 17th century. 164X118. Budapest. F. Batari. Ottoman-Turkish Carpets. 


\section{Paintings of Master John}

Catherine Parr (1512-1548) portrayed by Master John who is a mysterious figure is the sixth wife of Henry VIII of England and became the Queen of England after marrying Henry in 1543. She is the last queen of Tudor dynasty. Her nameless book published with the title "Antiphons and Prayers" in 1543 is the first book of a queen (Susan, 2009).

Whether the person illustrated in the painting which is exhibited National Museum in London is Catherine Parr or Lady Jane Gray became a question of debate and in consequence of the researches and analyses, it was discovered that the portrayed woman is Catherine Parr (Williamson, 2010, p. 91) (Gittings, 2006, p.14) (James, 1996, p.20-24). The queen was depicted on a carpet of Bergama prayer rug type that was found to be produced in Western Anatolia. In general, yellow, walnut green and red were used in Bergama prayer rugs. Its single and double-triangle niches, hanging oil lamp and angled bent branch motifs are seen. In borders, there are stylized flowers with bent branches, s curves, knots and schematic clover leaves.
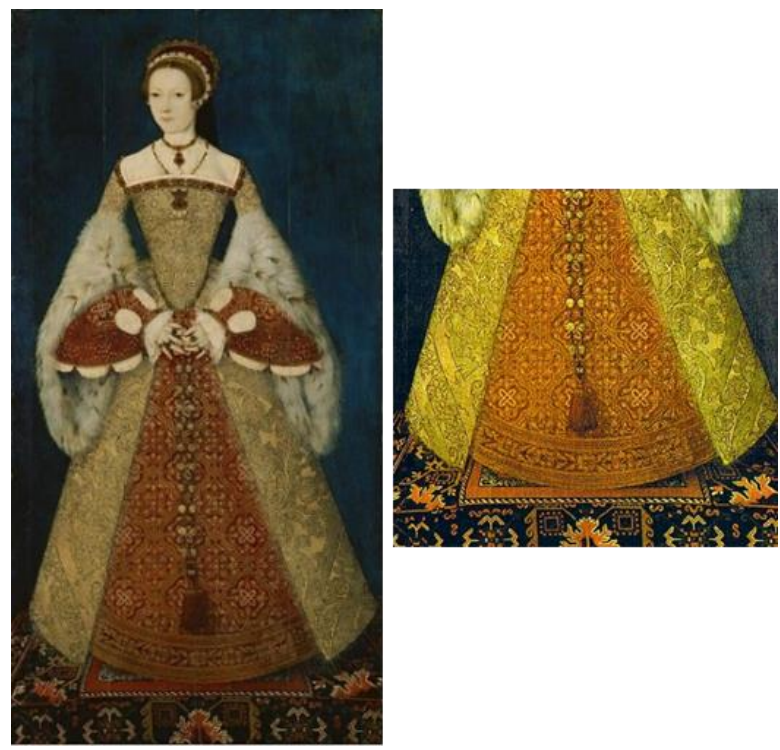
Gallery.

Figure 31. Master John. Queen Catherine Parr, 1545, National Portrait 


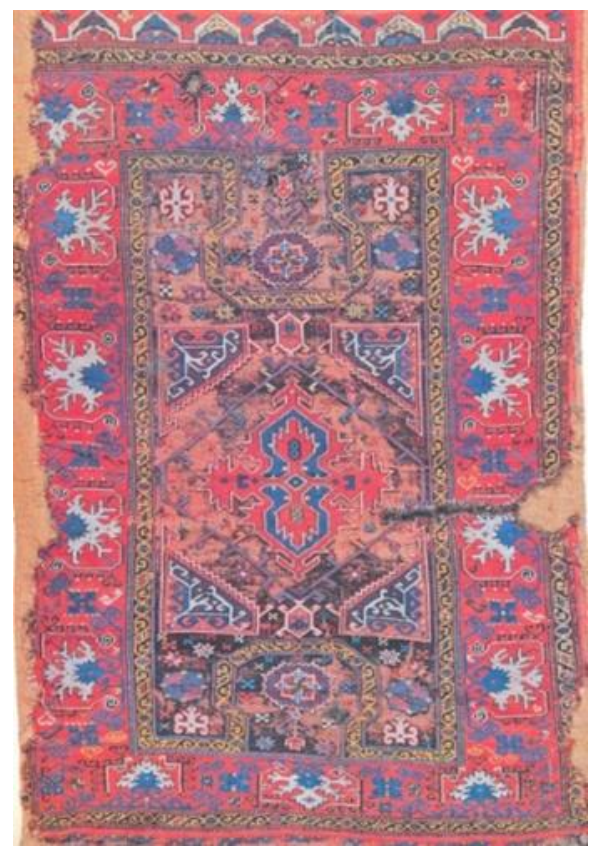

Figure 32. 16th century. Bergama carpet, Museum of Turkish and Islamic Arts.

\section{The British carpets under the influence of Turkish carpets}

It is known that several carpets which resemble the Ottoman carpets were woven in England. In each of three carpets of Buccleuch dukes in Boughton House which is based on the star patterned Uşak carpets, there is an emblem of Montagu family in center of the borders. 1584 and 1585 are written in two of these works. According to Donald King, the letters included in especially the borders of the star-patterned carpets in Boughton represent the initials of the weaver. Border and center of the carpet dated 1585 contain A.N. and E.N., respectively. King associated the relevant three carpets and another Lotto carpet in the same collection that takes Uşak carpets as a model, with an English atelier (Sherill, 1996, p.136).

Motifs of these four carpets are very similar to those of the Anatolian Uşak carpets. However, the color differences and throws and warps which are made of linen rather than of wool indicate the European origin of the carpets. It is thought that the said carpets were woven in an English atelier in the late 16th century and, 


\section{Hülya KALYONCU}

in the early 17 th century together with a group of carpets in which similar techniques were applied and English emblem is made (King and Slyvester, 1983, p.69-71) (Sweetman, 1988, p.16).
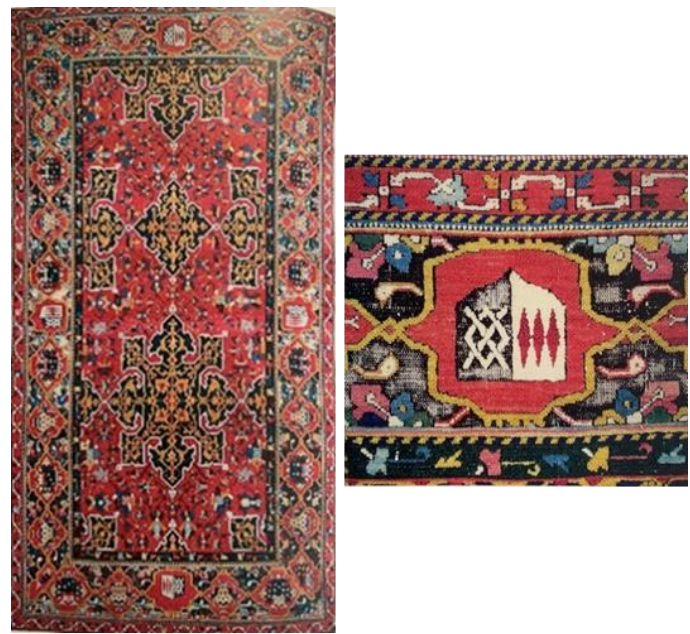

Figure 33. British carpet with Montague emblem and detail, 1585, Duke of Buccleuch, Boughton House, Kettering, Northamptonshire

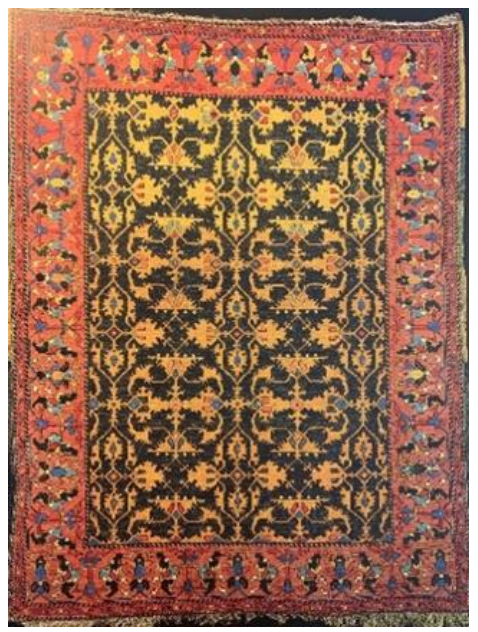

Figure 34. British carpet (imitation of Uşak carpet with Lotto pattern), Duke of Buccleuch, Boughton House, Kettering, Northamptonshire. 
Model of a carpet exhibited in Victoria and Albert Museum is based on the Ottoman Bergama carpets called as small pattern Holbein carpets. This carpet dated 1603 has the emblems of Thakeham knighted in the same year, and of Sir Edward Apsley from Sussex and Elizabeth Elmes from Northampstonshire, Lilford (Sherill, 1996, p.141-142) on its three sides. Text on the sides are as follows: Fear god and keep his commandments, Made in the year 1603 (Atasoy and Uluç, 2012, p.214). Stylized kufi border of the carpet takes the border of the Ottoman carpets.
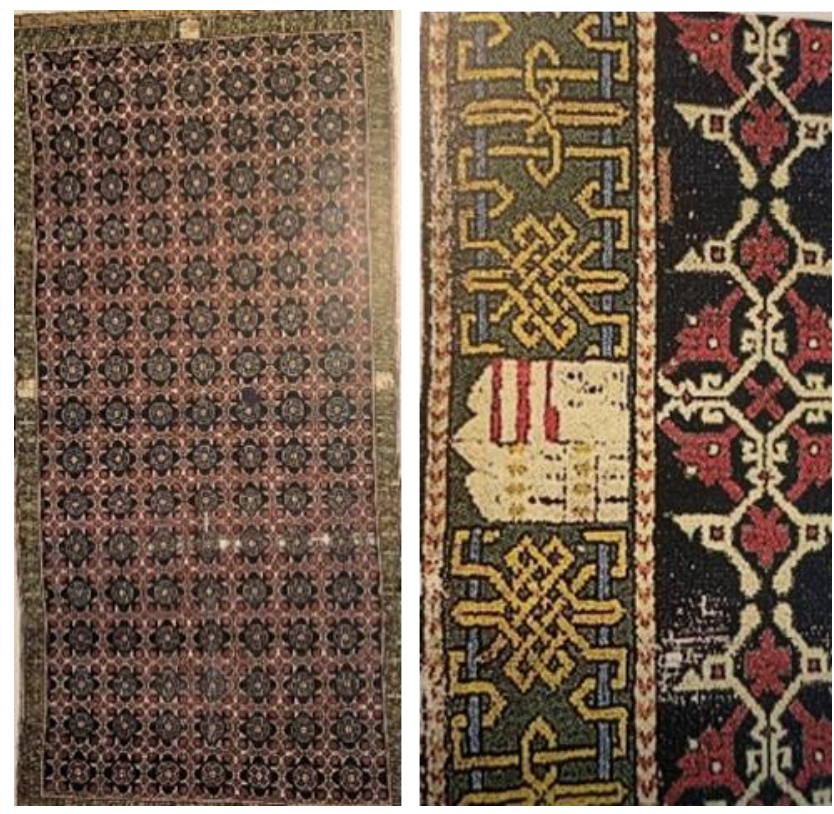

Figure 35. British carpet and border detail, 1603, Victoria and Albert Museum, London, inv. no: 710-1904.

Such carpets are mentioned in British inventories both as "Turkey Carpets" and "Turkey work carpets". Even though there not any common view on the literal meaning of these expressions, for a researcher, "Turkey Carpets" is the general name of the carpets imported from the Ottoman Empire. "Turkey work carpets" is their British imitations (Y1ld1z, 2002, p.575). On the other hand, Donald King specified that Turkey work phrase refers to knot style rather than origin (King, 1987, p.22). Another researcher asserted that both terms are used 
for both exported and knotted local carpets (Sherill, 1996, p.132) (Atasoy and Uluç, 2012, p.215).

A group of needlepoint carpets contain the motifs inspired from the Ottoman models. The large and small patterns named as Holbein whose model is based on Bergama carpets were superficially used in the three carpets in the United Kingdom dating back to the 16th and 17th centuries. In one of these carpets kept in Victoria and Albert Museum, the pattern was imitated as large octagons and English-style flowers were placed between the octagons (Sherrill, 1996, p.138). Octagonal and starred Holbein motifs were utilized in the other two carpets (Sherrill, 1996, p.138-141).
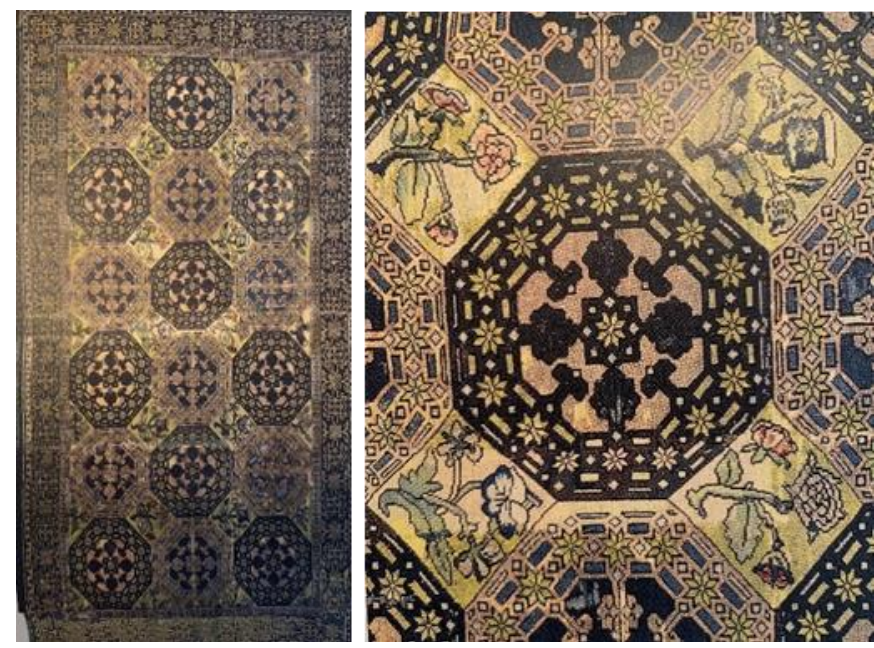

Figure 36. British needlepoint carpet and detail, 1603, Victoria and Albert Museum, London, inv. no: T.41-192.

It is seen that the British carpets were used in the Ottoman palaces beginning from the mid-19th century. Nevertheless, British community went on buying the Anatolian carpets even in this era. This situation continued until the early 20th century (Adanır and Öztürk, 2010). 


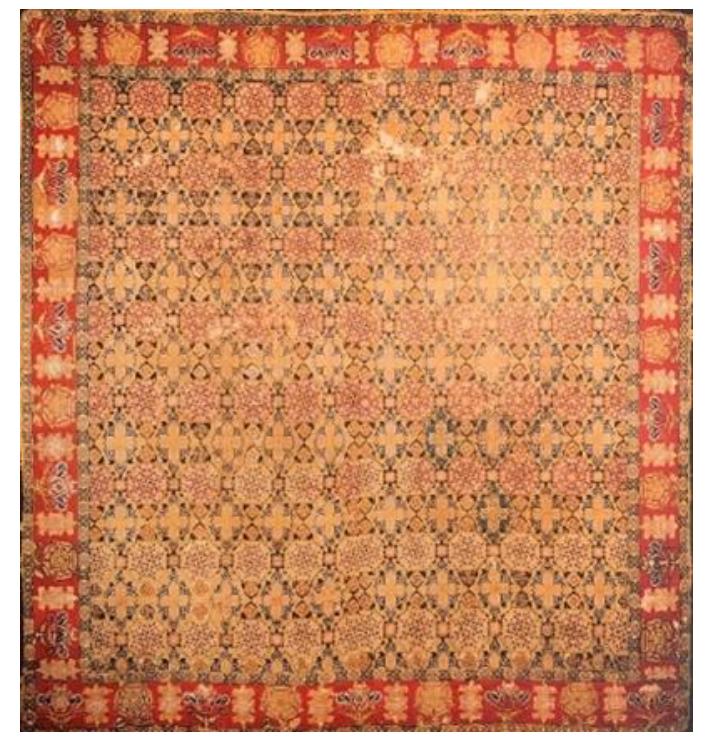

Figure 37. British needlepoint carpet, the late 16th century-the early 17 th century, Marquess of Salisbury, Hatfield House, Hertfordshire.

\section{CONCLUSION}

It is seen that the aim in evaluation of the Turkish carpets reflected on the European paintings is to date and classify the carpets. On the other hand, it was assessed based on the studies that such paintings should be analyzed for helping sorting out of the carpets by periods, showing the impact of Turkish carpet art on the European carpet art. It is apparent that the Renaissance artists who depicted English aristocrats in painting raised the value of these art works by using the Turkish carpets regarded as the symbol of power and wealth, as the leading element which has a visual and symbolic meaning and the indispensable components of their compositions, in addition to the striking colors and details.

It was concluded based on this study that the Anatolian carpets exported to Europe for centuries had an impact on England as well as many European countries, and that the British carpet manufacturers under the influence of the motif designs of these carpets which are illustrated in portraits of the English aristocrats produced the carpets with motifs and knots similar to Turkish carpets in the 16th century even though such carpets were not present in their tradition.

Our fundamental will for today's Turkish carpet art is the entire protection and advancement of the Anatolian-Turkish carpet art which significantly 
contributed to formation and development of the worldwide carpet art, and creation of the permanent values for the Turkish culture and art to be made by this field of art.

\section{REFERENCES}

Adanır, E. Ö. \& Öztürk, B. (2010). Osmanlı İmparatorluğu ve İngiltere arasindaki hali ticareti: Anadolu ve İngiliz Halıları. Akdeniz Journal of Art, 3 (5), 117126.

Aslanapa, O. (2005). Türk Halı Sanatının Bin Yılı. İnkılap.

Aksoy, E. (2010). Avrupall Ressamlarin Tablolarında Resmedilen Transilvanya Halıları Olarak Adlandırılan Batı Anadolu Halıları. STD, 211-235. eISSN 2149-6595.

Atalay, B. (1967). Türk Halıcılı̆̆ı ve Uşak Halıları. Türkiye İş Bankası-Kültür

Atasoy, N. \& Uluç, L. (2012). Osmanlı Kültürünün Avrupa'daki Yansimaları.1453-1699 Armaggan.

Ayaönü, Y. (2016). Erken dönem ortaçağ Avrupa tarihi (395-1000). Prof. Dr. Erhan Afyoncu (Ed.) Prof. Dr. Levent Kayapınar (Ed.), Ortaça $\breve{g}$ Yeniçă̆ Avrupa Tarihi içinde (s. 2-25). Anadolu Üniversitesi.

Cerasano, S. \& Davies, M. W. (1996). Renaissance Drama by Women: Texts and Documents. Routledge.

Çokay, M. Ö. (1999). XV-XVIII.yy Avrupası'nda masa örtüsü Türk halıları. Ev Tekstili, (22) Turkish Home Textile Industrialists' Association.

Erdmann, K. (1957). Der Turkische Teppische Des Jahrhunderts-15. Asır Türk Halısı (H.Taner, Çev.). İstanbul Edebiyat Fakültesi.

Ertuğ, A. (1969). Turkish Carpets from the 13th-18th centuries. Tekstilbank Kültür.

Fawcett, J. (1998-2001). Historic Floors, Their Care and Conservation. Architectural.

Franses, M. (2007). Erken Türk Halılarının Kısa Tarihi, Tanrıya Adanmış Halılar, Transilvanya kiliselerinde Anadolu halıları 1500-1750. Sakıp Sabanc1 Museum.

Frederick, D. (1836). Issue of the Exchequer of the Reign of the James 1. John Rodwell. 
Motif-Oriented Characteristics of The Turkish Carpets Illustrated in English...

Gittings, C. (2006). Tudors Ulusal Portre Galerisi Kitabı. Scala.

Gombrich, E. H. (1980). Sanatın Öyküsü. Remzi Kitabevi.

Gürçağlar, A. (1998). Yansımalar, gelenekler ve değişim. Antik\&Dekor Dergisi, (45), 154-160.

Hearn, K. (1995). Dynasties: Painting in Tudor and Jacobean England 15301630. Rizzoli.

James, R. N. (1896). Painters and Their Works. L.U. Gill.

James, S, E. (1996). Leydi Jane Gray veya Kraliçe Kateryn Parr. Burlington Magazine. 138 (1114): 20-24.

James, S. (2009). Catherine Parr: Henry VIII's Last Love. The History.

Jeffree. G. (2014). Leemput,, Remi van. Oxford University.

King, D. \& Sylvester, D. (1983). The Eastern Carpet in the Western World, from the 15th to the 17th century.

Maclean, G. (2009). Doğu'ya Bakış: 1800 Öncesi Dönem Ingiliz Yazmaları ve Osmanlı Imparatorluğu (Sinan Akıllı, Çev). ODTÜ Geliştirme Vakfi.

Mert, O. (1989). Halıcılığımız üzerine uşak halilari. Tekstil\&Teknik, (57).

Mills, J. (1975). Carpets in Pictures. National Gallery.

Mills, J. (1978). Early Animal Carpets in Western Paintings. Hall, I (3), 234-243.

Mills, J. (1978). Small Pattern Holbein Carpets in Western Paintings. Hall, I (4), s.326-334.

Mills, J. (1981). Lotto Carpets in Western Paintings. Hall, IV (I), 53-55.

Murray, P, L. (1996). Sanat ve Sanatçılar Sözlüğü. Penguen.

Nicolas, N, H. (1830). Elizabeth of York'un Özel Çanta Masrafları. W.Pickering,

Ölçer, N. \& Franses, M. (2007). Tanrıya Adanmış Halılar: Transilvanya Kiliselerinde Anadolu Halıları, 1500-1750. Sakıp Sabanc1 Müzesi.

Payne, H. (2004). Howard, Katherine, Countess of Suffolk, Oxford Dictionary of National Biography. Oxford University.

Polo, M. (1955). La Description du Monde (L. Hambis, Çev.). Librairie C.Klincksieck. 
Robert, W, K. (1970). Elizabeth's Admiral: The Political Career of Charles Howard, Earl of Nottingham, 1536-1624. The Johns Hopkins.

Rudenko, S. I. (1970). Frozen Tombs of Siberia-the Pazyryk Burials of Iron Age Horsemen (M.W. Thompson Çev.). University of California.

Sherill, S. B. (1996). Carpets and Rugs of Europe and America. Aberville.

Sönmez, Z. (2006). Türk-Ittalyan Siyaset ve Sanat ilişkileri. Bağlam.

Strong, R. (1969). The English İcon: Elizabethan and Jacobean Portraits. National Portrait Gallery.

Sweetman, J. (1988). The Oriental Obsession: Islamic İnspiration in British and American Art and Architecture 1500-1920. Cambridge University. Trakya Üniversitesi Sosyal Bilimler Dergisi (June 2011), 13 (1), 275-291.

Ungerer, G. (1998). Juan Pantoja de la Cruz ve 1604/5'te İngiliz ve İspanyol mahkemeleri arasinda hediyelerin dolaşimi. Shakespeare Studies, John Leeds Barroll (Ed.), Fairleigh Dickinson University, 145.

Williamson, D. (2010). Kings \& Queens. Ulusal Portre Galerisi.

Yetkin, Ş. (1993). Türk Halı Sanatı. Başlangıcından Bugüne Türk Halı Sanatı içinde (s.311-342). Türkiye İş Bankası.

Yetkin, Ş. (1981). Historical Turkish Carpets in Turkey. Türkiye İş Bankası Kültür.

Yetkin, Ş. (1964). İstanbul Türk ve İslam eserleri müzesinde bulunan bazı halılar ve rönesans ressamlarının eserleri. Türk Kültürü Araştırmaları, (2), .208222.

Yetkin, Ş. (1982). Türk halı sanatından bir teknik özellik. Vakıflar Dergisi, (XVI), 119-123.

Yıldız, N. (2002). İngiliz kültüründe osmanlı etkileri, Türkler (prep.for publ. Hasan Celal Güzel, Kemal Çiçek and Salim Koca'. Yeni Türkiye, 564-580.

\section{EXTENDED ABSTRACT}

Turkish carpets with a great importance in world's carpet history have their origins in Pazırik Carpet, the world's oldest and the first knotted carpet which was produced by the Central Asian Turks. Carpet tradition of Turks was kept by the Anatolian Seljuk Empire and it had its golden age with Ottoman Empire period. It is seen that these Turkish carpets usually made in Western Anatolia and 
Motif-Oriented Characteristics of The Turkish Carpets Illustrated in English...

Uşak were sent to Europe via business connections and their illustration in works of European painters started from the early Renaissance. The mostly depicted typings of Anatolian-Turkish carpets seen in those works are the Seljuk carpets with animal patterns or the Type I small plant-pattern Holbein carpets, the Type II Holbein carpets (Lotto carpets), the Type III large-pattern Holbein carpets, the Type IV large-pattern Holbein carpets, medallion and star carpets of the classical period and the Ottoman carpets known as the Transylvanian carpets. These carpets mentioned with the names of the Renaissance painters, Hans Holbein and Lorenzo Lotto due to being illustrated in their works added aesthetic value to the paintings as well as enhancing and coloring the compositions in which they are included.

The Turkish carpets of the classical period exhibited as the most important pieces of the world today were depicted in the compositions with crowded scenes and religion and society-thematic paintings in Italian, Flemish, Dutch and Spanish painting art. The commercial documents of the said carpets survived until today.

Another group with a great interest in Turkish carpets constitutes English aristocrats. A document owned by Antony Querris is the first document of the Turkish carpet mentioned in English sources. In this document which shows the tax exemption for the carpets bought for the high priest of the Monastery of Saint John in 1439, it is certified that Venetian and Genoese merchants bartered Turkish carpets for British wool carpets. The other significant English archive documents are about the Turkish carpets brought to England for Wolsey, the potent Cardinal of Henry, VIII period (1491-1547). The aristocrats such as Henry VIII, King of England from the Tudor Dynasty; Rochford Viscountess Dorothy St. John; Lady Carry; Catherine Knyvett, the countess of Suffolk; Sir Richard Sackville, member of English parliament; Thomas Sackville, 1st Earl of Dorset and English statesman; Queen Elizabeth, Margaret, the daughter of Henry VII and the Queen of Scotland; James I of England and James VI of Scotland; Charles Howard, 1st Earl of Nottingham; Henry Hasting, 5th Earl of Huntingdon, Henrietta Anne, the Princess of England, Scotland and Ireland and Catherine Parr, the wife of Henry VIII of England are several English aristocrats portrayed with Turkish carpets by leading European painters.

As mentioned above, the Turkish carpets illustrated in these works have importance for being included in the European painting, particularly the portrays of English aristocrats. Besides, they have a substantial place in Turkish carpet history, since they influenced English carpet art with their similar motif-oriented characteristics and composition schemes. The carpets exhibited in significant museums of United Kingdom reflect these effects. 
In this study which searches the effects of Anatolian-Turkish carpets illustrated in portrays of English aristocrats on English carpet art, the paintings of Renaissance period which are presented in various museums around the world and contain the compositions, including Turkish carpets by the European painters, the portrays of English aristocrats depicted with Turkish carpets and the relevant literary sources were reviewed. Furthermore, the paintings in museums were classified by periods and patterns were evaluated through comparisons and similarities and the connections with similar features were revealed.

It was concluded that the Anatolian carpets exported to Europe for centuries influenced England as well as numerous European countries and the English carpet makers who were affected by motif designs of these carpets illustrated in the portrays of English aristocrats produced motif and knot-effect Turkish carpets from the 16th century even though it is not in their traditions and traditional characteristics of the Anatolian-Turkish carpet art which contributed to the emergence and development of world carpet art should be preserved and advanced at all points. 